\title{
Matki i córki w polu autobiograficznym
}

\section{Aleksandra Grzemska}

TEKSTY DRUGIE 2018, NR 6, S. 77-91

DOI: $10.18318 /$ td.2018.6.5

Tylko dzięki sztuce możemy wyjść poza siebie, dowiedzieć się, co widzą inni z tego świata, który jest nie ten sam co nasz...

Gilles Deleuze ${ }^{1}$

Wierzę w coś takiego jak prawda.

Wolę jednak, gdy prawda pojawia się w sztuce, literaturze, i tam przeciwieństwem prawdy także jest prawda.

\section{Potencjały e(ste)tyczne i performatywne}

W myśleniu o estetycznej reprezentacji zespolonej z artykulacją doświadczenia należy wziąć pod uwagę sytuację odbiorczą wytwarzaną przez autorkę/autora w narracji autobiograficznej, silnie związaną z praktyką artystyczną

1 G. Deleuze Proust i znaki, przeł. M.P. Markowski, słowo/obraz terytoria, Gdańsk 2000, s. 43.

2 Wypowiedź Susan Sontag w wywiadzie stanowiącym fragment filmu dokumentalnego W sprawie Susan Sontag (Regarding Susan Sontag), reż. N.D. Kates, scen. N.D. Kates, J. Haptas, USA, HBO, 2014, 95 min. 
i wpisaną w nią biografią. W aranżacji tej sytuacji tkwi bowiem potencjał performatywny - wychodząc od kreowania, inscenizowania „ja”, podmiot nakierowany jest na stawanie się, wyzwolenie, ale także na komunikację ${ }^{3}$ i interwencję. Jeśli przyjąć definicję performatywności „jako przeświadczenie, że język nie tylko przedstawia rzeczywistość, lecz także powoduje w niej zmiany, a ponadto, że pewne zjawiska istnieją tylko w akcie ich wykonywania i że muszą być powtarzane, by zaistnieć" ", to podmiot praktyk artystycznych - nastawiony na działanie (to perform) i sprawczość (agency) - staje się podmiotem performatywnym.

Sekwencja przywołanych z przeszłości zdarzeń i ich usytuowanie w narracji autobiograficznej sprawia, że „afektywna syntaksa"5 uruchamia proces interferowania między inscenizacją (literacką i/lub wizualną) a wywołanym w adresacie i odbiorcy poruszeniem. Akt performatywny pełni zatem funkcję bufora między działaniem a odczuwaniem i rozumieniem. Widmowy charakter przeszłości - przeżywanej w teraźniejszości, uobecniony przez opowieść, obraz - pozwala na literackie lub wizualne wywołanie z pamięci tego, co nieobecne, oraz przemyślenie, przewartościowanie własnego względem niej umiejscowienia. Docieranie do zakodowanych poziomów emocji jest skomplikowaną operacją chociażby przez to, że proces opisu, zliteralizowania emocji wiąże się z poddaniem ich ocenie z perspektywy współczesnej pozycji i samowiedzy podmiotu, poddaniem ich analizie, krytyce i cenzurze ${ }^{6}$.

Zaangażowanie podmiotu narracji autobiograficznej w wyobrażenie sobie etapów dochodzenia do samoświadomości oraz w ekspresję własnego intymnego języka wzbudza pewien rodzaj dyskomfortu, wywołuje „zmącone

3 Inga Iwasiów twierdzi, że „autobiograficzny trójkąt «przepisany» narzędziami krytyki feministycznej mógłby wyglądać tak: tożsamość-performans-komunikacja. Kolejność modyfikuje tę utrwaloną w «oryginalnym» trójkącie Małgorzaty Czermińskiej”, tejże Tożsamość, performatywność, komunikacja - genderowe aspekty autobiografizmu, „Autobiografia. Literatura, Kultura, Media" $2014 \mathrm{nr} 1$ (2), s. 9.

4 E. Domańska „Zwrot performatywny" we współczesnej humanistyce, "Teksty Drugie” $2007 \mathrm{nr} 5$, S. 49 .

5 Termin Mieke Bal Afekt jako siła kulturowa, przeł. A. Turczyn, w: Historie afektywne i polityki pamięci, red. E. Wichrowska, A. Szczepan-Wojnarska, R. Sendyka, R. Nycz, Wydawnictwo IBL PAN, Warszawa 2015, s. 33-46. „Afektywna syntaksa” wskazuje na to, że intensywność afektów wywołanych w odbiorcy zależy od konstelacji danych elementów, czy to ekspozycji, czy formy narracji, nie zaś od poszczególnych komponentów.

6 Pisze o tym więcej A. Marglit Emocje przypomniane, przeł. T. Kunz, w: Historie afektywne i polityki pamięci..., s. 65-94. 
emocje"7 ze względu na głęboko wpisane w kulturową praktykę przedstawiania kategorie etycznej odpowiedzialności oraz waloryzację opowieści o życiu (swoim czy rodzinnym). Gdy zatem podmiot praktyk artystycznych, podmiot performatywny, zmierza do wyjścia poza etyczne struktury przedstawiania wydarzeń minionych - przede wszystkim zaś doświadczeń intymnych, traumatycznych, granicznych - to za pomocą praktyk artystycznych umocowanych na autobiograficznym podłożu czy „estetyki afektywnej”8 próbuje nie tyle "przekazać sens własnej legendy", ile dokonać transformacji Życia, Historii w obiekt artystyczny odzwierciedlający o wiele bardziej idiomatyczność doświadczenia.

Kobiece pisanie autobiograficzne wyróżnia się charakterystycznym umiejscowieniem podmiotu we wspólnocie doświadczeń; wspólnocie rodzinnej, pokoleniowej, ale także emocjonalnej/afektywnej, intelektualnej, wyobrażonej, instytucjonalnej, środowiskowej, dyskursywnej. Kobiecy podmiot performatywny zazwyczaj nie jest podmiotem samotnym, lecz współdziała (często nawet nieświadomie) z innymi podmiotami, „aktorami” przestrzeni społecznej. Jeśli „naczelnym, podstawowym założeniem performatyki jest [...] otwartość jej pola"10, a w horyzoncie doświadczenia granice działania i sprawczości podlegają ciągłym przemieszczeniom uzależnionym od praktyk oraz dyskursów społecznych, to podmiot zorientowany na konceptualizowanie własnej tożsamości - szczególnie podmiot kobiecy, którego pisarstwo jest silnie uzależnione od warunków, umiejscowień i relacji społeczno-politycznych oraz praktyk codziennych"1 - a także podejmujący refleksję dotyczącą siebie migruje między poszczególnymi punktami w polu autobiograficznym.

7 O kategorii „zmąconych emocji” pisze Marek Zaleski, odwołując się do rozpoznań Sianne Ngai, autorki książki Our Aesthetic Categories. Zany, Cute, Interesting, Cambridge, MA-London 2012. Zob. M. Zaleski Estetyka zmąconych emocji, czyli estetyka zwykłości - o Dorocie Masłowskiej dwukrotnie, w: Historie afektywne i polityki pamięci, s. 95-138.

8 Zob. M. Glosowitz Estetyka afektywna. Zarys metodologii badań literackich, w: Historie afektywne i polityki pamięci, s. 61-62.

9 G. Gusdorf Warunki i ograniczenia autobiografii, przeł. J. Barczyński, w: Autobiografia, red. M. Czermińska, Słowo/Obraz Terytoria, Gdańsk 2009, s. 45. R. Schechner Performatyka:wstęp, przeł. T. Kubikowski, red. przekł. M. Rochowski, Ośrodek Badań Twórczości Jerzego Grotowskiego i Poszukiwań Teatralno-Kulturowych, Wrocław 2006, s. 15.

11 W szerszym kontekście, uwzględniającym polityczne aspekty relacyjnego umiejscowienia podmiotu kobiecego, zob. Polityki relacji w literaturze kobiet po 1945 roku, red. A. Grzemska, I. Iwasiów, Wydawnictwo Naukowe Uniwersytetu Szczecińskiego, Szczecin 2017. 
W tym celu korzysta z modeli pisarstwa wypracowanych w jego obrębie lub poddaje je autorskiej transformacji.

Zaproponowana przeze mnie kategoria pola autobiograficznego nie funkcjonuje jako ustabilizowane pojęcie badawcze. Ma ona dalekie odniesienia do sformułowanej przez Pierre'a Bourdieu kategorii pola literackiego ${ }^{12}$, którą najogólniej, w dużym uproszczeniu można rozumieć jako „strukturę relacji” między osobami, praktykami i przedmiotami, odpowiadającymi konkretnym obszarom aktywności ${ }^{13}$.Zastosowana analogia pozwala mi na odwołanie się do tych badań nad autobiografią, które wychodzą poza genologię ku szerokiemu kontekstowi, zadając pytania o uwarunkowania tworzenia narracji autobiograficznej. Odróżnienie autobiografii oraz kierujących nią strategii od literatury i jej instytucji wydaje się zasadne z powodu tradycji oraz funkcji intymistyki, lokowanej na przecięciu faktografii i fikcji. Pole zbiera pojęcia takie jak tekst, podmiot, ranga, obiegi, archiwa, gest autobiograficzny, pakt, ślad oraz wiele innych. W jego ramach bez wątpienia mieszczą się takie pojęcia jak kobiecość, rodzina, a także procesy mówienia/pisania o nich.

Wewnętrzną strukturę pola autobiograficznego opisałabym zatem jako wielowarstwową sieć, która nie tyle opiera się na binarności i opozycji, wertykalnie konstruowanej hierarchii, ile uwzględnia także architekturę zawiłych procesów i praktyk twórczych wpływających na funkcjonowanie relacji i ich reprezentację. Łączy się to z uwikłaniem podmiotu/podmiotów narracji autobiograficznej w układy siły i wulnerabilności, autonomii i heteronomii, władzy i współbycia, zaangażowania i dystansu. W odniesieniu do badanej w tym miejscu relacji matka - córka należy poszerzyć rozumienie pola autobiograficznego o takie aspekty jak zasady podmiotowego samostwarzania oraz asymetrię doświadczeń zespoloną z umiejscawianiem ról i pozycji wewnątrz układów rodzinno-społecznych, ale także wewnątrz narracji. Kwestie dysponowania auto/biografią, opierające się na limitowaniu szczerości, rozważaniu i negocjowaniu tego, co można powiedzieć za kogoś i/lub o kimś, splatają się z warunkami, w jakich „Ty” matki staje się dla "Ja" córki obce/Inne lub bliskie/intymne, a także gdy „Ja" zaczyna stawać się „Ty”.Ta problematyka selekcjonowania, uzupełniania, odrzucania, a także zastępowania czy analogizowania doświadczeń cudzych i własnych

Zob. m.in. P. Bourdieu Reguły sztuki. Geneza istruktura pola literackiego, przeł. A. Zawadzki, Universitas, Kraków 2007.

13 Tamże, s. 406. A także G. Jankowicz, P. Marecki, A. Palęcka, J. Sowa, T. Warczok Zamiast wstępu. Literatura polska po 1989 roku w świetle teorii Pierre'a Bourdieu, "Praktyka Teoretyczna” 2014 $\mathrm{nr} 1$ (11), Socjologia literatury, s. 8-21. 
związana jest z intencjonalnością oraz relacyjnością. Wszystko to zaś wtłoczone jest w praktyki twórcze i codzienne oraz mechanizmy ujmujące w konwencje proces wspominania i auto/biografizowania.

Pole badanej relacji odnoszę również do elastycznego, wielokształtnego i wymykającego się regułom habitusu jako systemu dyspozycji nabytych przez jednostkę - a także rodzinę w ogóle - na drodze poszczególnych doświadczeń, zajmowanych pozycji. Habitus nastawiony jest na działanie, to w zasadzie osobisty styl poddający się nieustannym przemianom, struktura wewnętrzna odzwierciedlająca społeczne trajektorie. Rutynowy, ale niekoordynowany i niedyskursywny charakter habitusu sprawia, że podmiot - tym bardziej w relacji z innymi podmiotami - ukształtowany według silnie zakorzenionych scenariuszy zachowań składających się na obraz i odbiór świata, a także wywołujących określone reakcje, nie zawsze i nie do końca uświadamia sobie działanie mechanizmów społecznych kształtujących relacje rodzinne. Kluczowe jest zatem to, że podmiot tkwiący wewnątrz rodzinnego habitusu nie jest w stanie wyartykułować tego, czego nie jest świadomy i co wymyka się poziomowi pozadyskursywnemu, nie jest w stanie go na nowo wytworzyć, transformować, zaktualizować. Jest to możliwe tylko wtedy, gdy wychyli się poza ramy określonej struktury, gdy - pozostając w granicach pola - przetransportuje się na margines ${ }^{14}$ i dostrzeże wzajemne uwikłania w innej perspektywie, spróbuje uchwycić powidoki rodzinnych relacji i zająć pozycję narracyjną. W tym kontekście ważne jest zatem przeanalizowanie, w jaki sposób w strukturze pola autobiograficznego układa się/jest układany system dyspozycji w rodzinie, szczególnie w relacji matka-córka. Siatka czy też konstelacja rodzinnych korelacji unaocznia, w jaki sposób potencjały: etyczny, estetyczny, performatywny itd. funkcjonują jako wielkości charakteryzujące stan pola autobiograficznego.

\section{Konfrontacje i sojusze}

Kiedy wszystko wokoło się chwieje, jedynym punktem oparcia jest własne ja.

Kiedy twarze wokoło stale się zmieniają i nikną w mroku, jedyną wyraźną twarzą jest własne oblicze.

Virginia Woolf Krzywa wież ${ }^{15}$

14 Margines rozumiem za bell hooks Teoria feministyczna. Od marginesu do centrum, przeł. E. Majewska, Wydawnictwo Krytyki Politycznej, Warszawa 2013; tejże Margines jako miejsce radykalnego otwarcia, przeł. E. Domańska, "Literatura na Świecie” 2008 nr 1/2, s. 108-117.

15 V. Woolf Krzywa wieża, w: tejże Eseje wybrane, przeł. M. Heydel, wyb. i oprac. M. Heydel, R. Sendyka, posł. R. Sendyka, Karakter, Kraków 2015, S. 137. 
O tym, że performatywne akty twórcze nabierają charakteru praktyk artystycznych realizowanych $\mathrm{w}$ polu autobiograficznym, decyduje przede wszystkim to, iż podmiot za pomocą reminiscencji aktywuje pamięć faktograficzną i zmysłową na potrzeby stworzenia nie tyle pojedynczego obiektu mającego reprezentować konkretne wydarzenia, momenty z życia, ile po to, by przez powtarzalne działania artystyczne utrwalić własną podmiotowość wpisaną w szerszy kontekst, ustanowić własny „zwrotny, relacyjny, «skręcony» i «zaimkowy», niejednorodny i wielogłosowy model siebie"16. Rytuały formowania w polu autobiograficznym własnego doświadczenia w rodzinnym habitusie, w konstelacji z matką, stanowią ważny element wytwarzania autonomicznej jednostkowości, choć autonomia ta zawsze splata się z negocjowaniem pozycji względem społeczno-rodzinnych uwikłań i zależności (nie zawsze negatywnych). Projekt zapisywania życia w (literackiej i/lub wizualnej) twórczości, oparty na konfrontacji rzeczywistości minionej i współczesnej z jej intymną wersją, nie tylko podlega procesom scalania rozproszonych opowieści, ale przede wszystkim ma na celu wyłonienie autoportretu autorki auto/biografii spośród tła sylwetek rodzinnych. Co ważne, w strukturę pola autobiograficznego wpisane są interakcje i relacje, które przez akt autopojezy (samostwarzania) ${ }^{17}$ nie tylko wpływają performatywnie na formę przedstawienia i sytuację odbiorczą, ale także zasilają mechanizmy cyrkulacji biografii.

Relację matka-córka w polu autobiograficznym badam na przykładzie wybranej twórczości Ewy Kuryluk i Zuzanny Janin w kontekście praktyk artystycznych ich matek - Marii Kuryluk (Miriam Kohany) i Marii Anto. W swojej sztuce artystki podejmują bowiem takie problemy i operują takimi narzędziami, które stanowią przedmiot badań e(ste)tycznych, performatywnych, autobiograficznych. Kuryluk i Janin posługują się środkami artystycznymi silnie związanymi z ich biografią, dzięki czemu procesy introspekcji i uzewnętrzniania, rejestrowania siebie oraz własnego i rodzinnego życia za pomocą różnych mediów sztuki (malarstwa, fotografii,

16 R. Sendyka Od kultury "ja” do kultury "siebie”. O zwrotnych formach w projektach tożsamościowych, Universitas, Kraków 2015, s. 8.

Na temat autopojezy w teorii performatywności zob. więcej: E. Fischer-Lichte Estetyka performatywności, przeł. M. Borowski, M. Sugiera, Księgarnia Akademicka, Kraków 2008. W badaniach systemów społecznych pojęcie autopojezy wprowadził Niklas Luhmann Systemy społeczne. Zarys ogólnej teorii, przeł. M. Kaczmarczyk, Nomos, Kraków 2012. Na temat tego ujęcia zob. też: Luhmann: teoria systemów autopojetycznych, w: J. Szacki Historia myśli socjologicznej. Wydanie nowe, PWN, Warszawa 2003, s. 935-944. 
rzeźby, instalacji przestrzennej, filmu, literatury) pozwalają im na autoekspresję, w której zawiera się próba ujęcia kluczowych kwestii: reprezentacji, doświadczenia i (re)konstrukcji podmiotowości. Choć obie zaznaczają, że ich sztuka dotyczy uniwersalnych czy ogólnoludzkich kwestii ${ }^{18}$, to nie odżegnują się od interpretowania swoich dzieł w kategoriach autobiograficzności, a nawet akcentują znaczenie prywatnych, rodzinnych relacji oraz ich wpływu na biografię i sztukę ${ }^{19}$.

Relacja między córką-artystką a matką-artystką odgrywa tutaj niebagatelną rolę. Kuryluk i Janin - oczywiście nie w ten sam sposób i na innych etapach życia - musiały sprostać identyfikacji ze znanymi, utalentowanymi matkami/rodzicami zarówno we własnej świadomości, jak i w opinii publicznej. Życie i tworzenie w odniesieniu do sztuki uprawianej przez matki, pozostawanie w ich cieniu, realizowanie ich marzeń lub wymagań oznaczało dla młodych adeptek artystycznej wspólnoty konieczność konfrontacji. Przebiegały one na różnych poziomach: od polemik na temat wyboru dziedziny sztuki (muzyka, malarstwo, taniec, literatura) i stosowanej poetyki przez konflikty dotyczące krytyki lub uznania twórczych dokonań aż po paralelne postrzeganie wzajemnych praktyk artystycznych w kategoriach kontynuacji lub zerwań, a także, co ważne, zderzenie z niewiedzą o niektórych z nich. W przypadku obu artystek, choć w różnych momentach ich artystycznej drogi, konfrontacje zazwyczaj wiązały się z odróżnieniem, odrzuceniem, buntem, co oczywiście nie było przyjmowane przez matki bez konsekwencji - etapy wybicia na niepodległość wywoływały w nich zarówno dumę, poczucie sprawstwa, jak i żal, ból czy nawet zazdrość.

18 "[...] chciałabym podkreślić, że moje prace nie są autobiograficzne, choć inspirują mnie własne przeżycia. Szukam takich, które są uniwersalne, w których mogę pokazać historie wspólne. To nie jest krążenie wokół siebie po to, by mówić o sobie, ale by pokazać przecięcie pamięci wspólnej i osobistej. [...] Biografia jest tu traktowana subwersywnie. To nie temat, ale narzędzie. [...] Czasem warto użyć swojej biografii, by dowiedzieć się czegoś znacznie bardziej uniwersalnego. To jest właśnie moja metoda pracy". Taniec dla Marii i Nelly. ZZuzanną Janin rozmawia Małgorzata Czyńska, w: Zuzanna Janin. Biała kruk / White She-Raven, Fundacja Lokal Sztuki, Lublin-Warszawa 2016, s. 65, 77.

19 „Przecież tak naprawdę możemy pisać tylko o naszym życiu - cały świat dociera do nas przez zmysły - oczy, uszy, nos, dotyk - kształtuje się w umyśle. O czymkolwiek byśmy pisali, zawsze jest to «autobiograficzne»". [...] To z szaleństwa, które mam po mamie, powstaje moja sztuka. Artystka musi z natury rzeczy odbiegać od normy, gdyż ma za zadanie wyrazić nie normę, ale całą skalę życia. Artyści w «normie», to artyści słabi". Piękny dzień. Rozmowa Ewy Kuryluk z Agnieszkq Drotkiewicz, "Dwutygodnik” 2009 nr 15, http://www.dwutygodnik.com/artykuI/525-piekny-dzien.html (9.08.2017). 
O takim aspekcie macierzyństwa zakorzenionego w etyce nieobojętności, troski i jednocześnie obfitującego w emocje silnego przywiązania i idiosynkrazji pisała Adrienne Rich:

Moje dzieci stanowią przyczynę najbardziej bolesnego cierpienia, jakiego doświadczam. To cierpienie ambiwalencji: mordercze przechodzenie od gorzkiej niechęci i nadszarpniętych nerwów do błogiego zadowolenia i czułości ${ }^{20}$.

Wzajemny ambiwalentny układ matki i córki, oparty zawsze na nakładających się uczuciach miłości i cierpienia, zostaje dodatkowo skomplikowany, gdy do głosu dochodzi kwestia artystycznych ambicji lub trudności w ich spełnieniu.

W przypadku Ewy Kuryluk wiązało się to przede wszystkim z tym, że Miriam Kohany była utalentowaną pianistką i poetką, która na skutek Holokaustu (w którym zginęła cała jej rodzina oprócz najstarszego brata Oskara) i wydarzeń powojennych (kariera polityczna męża, ukrywanie pochodzenia, choroba psychiczna) nie mogła kontynuować muzyczno-pisarskiej kariery, skupiając się głównie na życiu rodzinnym i próbie radzenia sobie z traumatyczną przeszłością w totalitarnej rzeczywistości. Co prawda Maria Kuryluk od razu po wojnie uczestniczyła w tworzeniu środowiska literackiego: zajmowała się w „Odrodzeniu” działem listów i nawiązywała kontakt z autorami lwowskich „Sygnałów”, cyklicznie publikowała teksty w „Odrodzeniu”, ,Nowej Kulturze”, ,Rzeczpospolitej”, tłumaczyła literaturę niemieckojęzyczną takich autorów jak Ingeborg Bachmann, Thomas Bernhard, Erich Fried, Horst Bienek, napisała wspomnienie o Zdzisławie i Zofii Bielińskich, którzy ratowali lwowskich Żydów w czasie okupacji, wydała także niewielką powieść dla młodzieży zatytułowaną Jędreki Piotr ${ }^{21}$. Przez cały wojenny okres Miriam Kohany prowadziła zapiski w kajetach, które Ewa Kuryluk odnalazła dopiero po jej śmierci. Córka nie znała zatem w pełni literackiej twórczości matki sprzed 1945 roku, nie wiedziała, że ta tworzyła poezję w języku niemieckim, notowała recenzje swoich lektur, zaczęła pisać powieść o rodzinie.

Odkrycie przez pisarkę artystycznych dokonań matki odegrało znaczącą rolęw rekonstruowaniu jej portretu, wywołało potrzebę poszukiwań zatartych śladów historii i twórczości, w pewien sposób uruchomiło zainteresowanie,

\footnotetext{
20 A. Rich Zrodzone z kobiety. Macierzyństwo jako doświadczenie i instytucja, przeł. J. Mizielińska, Sic!, Warszawa 2000, s. 57-58. 
a także potrzebę wyjaśnienia i zrozumienia jej biografii poza tym, co córka znała z codziennego, dość trudnego z nią obcowania. Ewa Kuryluk wyznała bowiem wielokrotnie, że funkcjonowanie w domu przesyconym chorobą psychiczną matki, a później brata oraz żałobą po nagle zmarłym ojcu było nie do zniesienia, wywoływało eskapizm i odrzucenie, ratunkiem zaś była artystyczna twórczość, a w pewnym stopniu również emigracyjny dystans. Choć artystka wiedziała wcześniej o muzyczno-literackich fascynacjach matki, znała jej przesycone nostalgią opowieści o młodzieńczych marzeniach, to dopiero po odnalezieniu przedwojennej poezji ${ }^{22}$ - w znaczącym stopniu przewyższającej kunsztem powojenne teksty publicystyczne - ukazały się w pełniejszym wymiarze talent literacki oraz twórczy potencjał, które nie zostały wykorzystane. Wydaje się bowiem, że nasilająca się po wydarzeniach pogromu kieleckiego oraz po wyjeździe do Wiednia choroba Marii Kuryluk uniemożliwiała jej rozwijanie twórczości pisarskiej i na odwrót - niemożność realizacji ambicji artystycznych z pewnością miała niemały wpływ na pogarszanie jej stanu psychicznego.

Czas ten przypadł na początki odkrywania przez Ewę Kuryluk własnego talentu, który rodzice wspierali i kształtowali - dzięki podsuwanym przez matkę kanonicznym dziełom literatury niemieckiej, poznawanym w Wiedniu wybitnym dziełom malarskim, podróżom po Włoszech, pierwszym próbom fotograficznym artystka mogła uformować estetyczny zmysł i rozwinąć twórcze pasje. Postawa matki - niosąca zrozumienie i wolność dla wyborów córki, ale jednocześnie uciążliwa, toksyczna, wymagająca cierpliwości - okazała się zatem kluczowa w procesie odszukiwania i zgłębiania jej twórczości oraz spisywania opowieści o losach utalentowanej artystycznie Miriam Kohany, zanim już jako Maria Kuryluk została przede wszystkim żoną i matką żyjącą w ukryciu aż do śmierci.

Moja mama była strasznie trudna, uciążliwa. Po śmierci ojca, który zmarł stosunkowo młodo, stałam się głową domu. Przez całe dekady nie miałam cierpliwości do słuchania mamy, jej opowieści uważałam za banialuki, mitologie, chorobę. Zaczęłam słuchać mamy dopiero pod koniec jej życia, gdy choroba wyciszyła się dzięki opiece oddanego psychiatry, a może i dlatego, że stała nad grobem. A ja, po raz pierwszy w życiu, zadałam sobie trud, żeby jej wysłuchać i wziąć na serio. Zaczęło mi świtać w głowie, że na halucynacje zakrawająca historia ucieczki mamy 
z lwowskiego getta czy jej kult różowych kasztanów zahaczają o fakty. [...] Pewnie byłoby inaczej, gdybym znała ich historię. A nie znam jej właściwie do dziś, domyślam się jedynie, jak mogło być, rekonstruuję bieg wydarzeń. Ale nie da się wykluczyć, że popełniam błędy. Jak było naprawdę, to wiedzieli tylko moi rodzicie ${ }^{23}$.

Przywracanie przez Ewę Kuryluk portretu matki - opartego na jej zakamuflowanych i mistyfikacyjnych opowieściach, fragmentarycznych obrazach nieukładających się w spójną całość, tajemnicach odkrytych w archiwach po jej śmierci - prowokowało artystkę do analizowania nie tylko chronologii minionych faktów, ale przede wszystkim przyjrzenia się analogiom lub przeciwieństwom praktyk artystycznych przez pryzmat bezpośredniego pokrewieństwa. Dotarcie do prywatnych historii rodzinnych zmieniło priorytety i perspektywę - Maria Kuryluk nie pozostawała już jedynie schorowaną i starzejącą się, wymagającą uwagi matką, lecz przez przypomnienie twórczych pasji i dokonań zyskała jako Miriam Kohany własną biografię oraz podmiotowość, stała się dla córki partnerką, sojuszniczką i akuszerką jej artystycznych doświadczeń.

Inaczej proces ten wydawał się przebiegać w relacji między Zuzanną Janin a jej matką Marią Anto (Antoszkiewicz, z domu Czarnecką) ${ }^{24}$. Córka dorastała w domu, w którym dominowała intrygująca i ambitna matka-artystka, znana z surrealistycznego malarstwa, zamiłowania do plenerów w Puszczy Białowieskiej oraz wytrwałości w łączeniu obowiązków życia rodzinnego i wychowywania kilkorga dzieci z pracą twórczą, najpierw w powojennej, socrealistycznej rzeczywistości, a następnie w ogarniętej transformacją współczesności. W latach 6o. Anto ukończyła warszawską ASP, uczyła się malarstwa najpierw pod okiem prof. Stefana Płużańskiego, a później w pracowni prof. Michała Byliny, którzy wspierali jej rozwój i indywidualny styl.W czasie, gdy dominował koloryzm i abstrakcjonizm, Maria Anto nie należała do żadnej grupy artystycznej, pozostawała wierna swojej konwencji poetyckich wizji,

23 Piękny dzień. Z Ewą Kuryluk rozmawia Agnieszka Drotkiewicz, "Dwutygodnik" 2009 nr 15, http:// www.dwutygodnik.com/artykul/525-piekny-dzien.html (5.09.2017).

Wszystkie informacje biograficzne dotyczące Marii Anto czerpię z monografii jej poświęconych: Maria Anto, red. E. Olszewska, przeł. K. Lipnicka-Kołtuniak, Muza, Warszawa 2004; Maria Anto. Malarka, red. M. Jachuła, Zachęta - Narodowa Galeria Sztuki, Warszawa 2017; Krzyk. Zuzanna Janin o Marii Anto, w: R. Grzela Obecność. Rozmowy, Drzewo Babel, Warszawa 2015. Jestem wdzięczna również Zuzannie Janin za udostępnienie materiałów do analizy oraz za możliwość rozmowy inspirującej do podjęcia ważnych kwestii w moich interpretacjach. 
kojarzonej z malarstwem naiwnym czy kapizmem, lecz właściwej bardziej "metaforze malarskiej”, którą realizowała, odwołując się do instynktu, wyobraźni, metaforyki, fantasmagorii ${ }^{25}$. Dla kariery międzynarodowej Anto, rozpoczętej tuż po ukończeniu studiów, kluczową postacią był Ryszard Stanisławski - czołowy krytyk i historyk sztuki, wieloletni dyrektor Muzeum Sztuki w Łodzi oraz komisarz sekcji polskiej na Biennale São Paulo w 1963 roku, na którym wystawił 12 prac (przypominających sztukę Henri Rousseau) autorstwa młodej surrealistki z socjalistycznej Polski (matki dwóch córek: pięcioletniej Krystyny i dwuletniej Zuzanny). Obrazy nie wróciły do kraju, zostały sprzedane lub przekazane wybitnym znawcom i kolekcjonerom sztuki: Rosenthalowi, Chateaubriandowi, Matarazzy, o czym ich autorka nie wiedziała. W końcu lat 6o. i na początku 70. Anto była jedną z bardziej rozpoznawalnych i docenianych artystek polskich młodego pokolenia. Zdobyła międzynarodową sławę, głównie we Włoszech, dzięki promocji jej twórczości przez mediolańską Galerię d'arte Cortina oraz pisarza i dziennikarza Dino Buzzatiego. W tym czasie artystka nawiązała znajomości z artystami światowej sławy (Max Ernst, Dorothea Tanning), a podczas licznych wizyt namalowała na zamówienie serię obrazów i portretów.

Postać Stanisławskiego odgrywa epizodyczną, ale bardzo ważną rolę w rodzinnej relacji między matką a córką - podczas wystawy Zuzanny Janin w Galerii Foksal w 1998 roku spotkali się po 40 latach Stanisławski i Anto, która niespodziewanie przybyła na wystawę córki, co nie było oczywistą i typową sytuacją. Zaskoczenie spotęgował fakt, że krytyk docenił twórczość Janin, nie wiedząc o pokrewieństwie kobiet.

Maria przyszła niespodziewanie, bo wcale nie przychodziła zawsze. Widziałam, że szczególnie dla Ryszarda Stanisławskiego było to ważne spotkanie. Bardzo to przeżył. I nagle zorientował się, że ja, jego „odkrycie” tuż przed śmiercią, i Maria - jego odkrycie sprzed 40 lat - to córka i matka. To było dziwne. Bardzo dziwne. Niesamowite ${ }^{26}$.

Niesamowitość tego zdarzenia nie tyle polega na wyjątkowym zbiegu okoliczności, prowokującym do myśli na temat powtarzalności losów czy też fatalizmu, ile zwraca uwagę na pozycję Janin i jej sztuki względem artystycznych dokonań oraz biografii jej matki. Co prawda, dzięki celowej zmianie 
nazwiska oraz przez zupełnie różne poetyki twórczość Janin nie była/nie jest bezpośrednio kojarzona z pracami Anto, lecz artystka przez lata zmagała się z poczuciem odgrywania drugoplanowej roli względem matki-artystki, próbowała zdobyć przestrzeń wolności dla twórczych realizacji oraz negocjowała miejsce dla swej sztuki zarówno w artystycznym środowisku, jak i w relacji z krytyczną wobec jej wyborów rodzicielką. Proces ten utrudniał nie tylko "mroczny, gwałtowny i skłębiony"27, a nawet despotyczny temperament Anto, ale to, że - jak wyjaśnia Janin:

Mama wszędzie, gdzie się pojawiała, skupiała uwagę. To się zdarza artystom. Niektórzy muszą być w centrum, mówić wyłącznie o sobie, zawłaszczać przestrzeń i uwagę, nie widząc, że to czasem staje się zauważalnie krępujące dla wszystkich dookoła. Coś między zawłaszczaniem a rywalizacją. Trudno być może to zrozumieć ludziom spoza sztuki, ale obszar własny wystawy jest bardzo delikatną przestrzenią i łatwo kogoś zranić. Zresztą w obie strony. Czasem przychodząc, a czasem lekceważąc i nie przychodząc. Ja też nie potrafiłam się lepiej zachować i machnąć na to $\mathrm{req}_{\mathrm{ką}}{ }^{28}$.

Wydaje się zatem, że komplikacje i konflikty w tym związku polegały przede wszystkim na projektowaniu przez matkę losu córki, który ta stanowczo odrzucała na rzecz niezależności i wyzwolenia. Nawet jeśli Anto przekonana o artystycznych zdolnościach Janin - w młodości uczęszczającej do szkoły baletowej czy grającej w popularnym serialu Szaleństwo Majki Skowron $^{29}$ - próbowała dostrzec w córce potencjał w kontynuacji jej pasji do sztuki, to funkcjonowanie dwóch tak silnych twórczych osobowości w klinczu wzajemnych wymagań, niezrozumienia, zaborczości nie mogło przekształcić się w artystyczną matczyno-córczyną wspólnotę opartą na solidarności i sojuszu.

Rok przed śmiercią [matka] powiedziała do mnie: „Zawsze wierzyłam, Zuzanna, że będziesz moją bratnią duszą. A kiedy poszłaś na Akademię, że staniesz się moją przyjaciółką w sztuce". Tak nie było, bo myśmy się nie

ZMariq Anto rozmawia Małgorzata Bocheńska, w: Maria Anto, s. 54.

Krzyk. Zuzanna Janin o Marii Anto, s. 229.

29 Szaleństwo Majki Skowron, reż. S. Jędryka, scen. A. Minkowski, serial dziewięcioodcinkowy, 1976. 
rozumiały. Ona i ja to dwa całkowicie inne światy. Inne epoki. Skupiłam się na tworzeniu siebie, musiałam się wyemancypować od matki, co było bardzo trudne. A kiedy już się wyemancypowałam, zaczęły narastać konflikty. Byłyśmy mocnymi kobietami i każda miała swoje racje $\mathrm{e}^{30}$.

W tym przypadku pokrewieństwo okazało się znaczącym ciężarem, postać matki rzucała intensywny cień, zza którego córce trudno było się wydostać, by nawiązać komunikację - jeśli nie bezpośrednio, to przynajmniej na poziomie sztuki. Nie wydaje się, by Janin postrzegała swoją twórczość w kategoriach kontynuacji dokonań matki, a po jej śmierci w kategoriach obowiązku przywracania jej współczesnemu odbiorcy. We własnych dziełach, opartych przede wszystkim na relacji między pamięcią prywatną i wspólną, artystka próbuje raczej dać wyraz tej trudnej miłości dzięki temu, że matka staje się istotną i integralną częścią artystycznych projektów [między innymi Dziewczynki z cebula (Portret Matki) mówiącego o traumatycznych wydarzeniach z dzieciństwa matki w czasie wojny oraz Lost Butterfly o zaginionym obrazie przedstawiającym małą Zuzannę], jest elementem rzeźby, filmu, instalacji. Dopiero w ten sposób - przez medium sztuki - artystce-córce udaje się po partnersku zbliżyć do matki.

Zarówno Kuryluk, jak i Janin, posługując się metaforą w próbach reprezentacji doświadczeń, redefiniują strukturę relacji matka córka oraz ukazują rewers postrzegania jej w kategoriach integralności czy spójności, co wpisuje się w charakter zdefiniowanego przeze mnie powyżej pola autobiograficznego. Kładą nacisk na dostrzeżenie w tym wyjątkowo skomplikowanym układzie aspektów negocjowania własnej pozycji, poczucia i wyznaczania granic, warunków okazywania lub tłumienia uczuć. Rys autobiograficzny tej twórczości skłania do przemyślenia również kwestii „performatywnego interfejsu"31, czyli procesów identyfikacyjnych opartych na strukturach współodczuwania, które w różnych konstelacjach rodzinnych mogą przebiegać zupełnie inaczej i wywoływać odmienne reakcje. Uznając, że podstawą komunikacji i identyfikacji między matką a dzieckiem jest wizerunek, spotkanie twarzą w twarz, które uruchamia procesy ekspresji, należy pamiętać także o tym, że owa ekspresja podlega rytualizacji i modelowaniu podług utrwalonych mechanizmów. "Chwile performatywnego interfejsu" wydarzają się więc

30 Krzyk.Zuzanna Janin o Marii Anto, s. 216.

31 Pojęcie wprowadzone przez Mieke Bal Zagubienie: "gruntowna przemiana kwestii naszego «my»", przeł. T. Bilczewski, A. Kowalcze-Pawlik, w: Historie afektywne i polityki pamięci, s. 542-543. 
wtedy, gdy przez powierzchnię skonwencjonalizowanej ekspresji przebija autoprezentacja zawierająca w sobie także świadomość podmiotu odniesienia. Wzajemne przeglądanie się w sobie - matki w córce i córki w matce - może być próbą przełamania standardowych struktur relacji. „Zamiast «istnieć to znaczy być postrzeganym» lub «myślę, więc jestem», stawanie twarzą w twarz proponuje: «staję (wobec ciebie) twarzą w twarz, więc jesteśmy»"32. Taki układ współ-zależności pozwala na interakcję, a nie zawłaszczenie indywidualnych historii, oraz tworzenie opowieści o wzajemnych relacjach na zasadach dialogu, poza przymusem tkwienia w hermetycznym, narcystycznym klinczu. W odniesieniu do struktury pola autobiograficznego świadczy to również o tym, że system dyspozycji w rodzinie, zwłaszcza w relacji matka -córka, nie poddaje się jedynie strukturom hierarchicznym, lecz układa się wertykalnie, a nawet palimpsestowo, budując zagmatwaną sieć genealogicznych powiązań.

Nie można pominąć również tego, że i Kuryluk, i Janin ukazują w swej sztuce problem przypominania wydarzeń, które tak naprawdę nigdy nie zostały przez nie zapomniane, odnajdywania śladów nigdy nieutraconej pamięci, reprezentacji doświadczeń, które nigdy nie były ich własnymi bezpośrednimi doświadczeniami ${ }^{33}$. Praca artystek, podejmujących kwestię transgresyjnej transmisji traum matek oraz ich nieznanych młodzieńczych losów, opiera się zatem na projekcji wspomnień: na podstawie zebranych i scalonych rozproszonych fragmentów ich historii albo za pomocą (re)konstrukcji opowieści zasłyszanych, domysłów, wyobraźni artystki-córki próbują odkryć, ujawnić, przekazać dalej tajemnice matek i nadać ich losom artystyczną formę. Dzięki temu możliwy staje się proces transmitowania pamięci zakorzenionej we własnej nie-pamięci, by móc przerzucić most między podmiotami matczyno-córczynej relacji, a przez różnicowanie biografii dojść do ukazania wspólnoty doświadczeń. Fantazmatyczność oraz niemożliwość dotarcia do prawdziwej historii matek wkodowanej w pamięć i biografię córek, międzypodmiotowe/ międzypokoleniowe konfrontacje i sojusze oraz afektywne reakcje na ślady nieznanej przeszłości zasilają sztukę i literaturę, jednocześnie uruchamiając mechanizmy „stawania się", konstytuowania podmiotowości.

Tamże, s. 511.

Koncepcję tę rozwija w bardzo interesujący sposób B.L. Ettinger Transkryptum: tropienie śladów pamięci z/w/z myślq o Innym, przeł. A. Chromik, A. Kisiel, "Narracje o Zagładzie” 2016 nr 2, s. 103-112. Szerzej interpretuję twórczość Kuryluk i Janin w kontekście teorii Ettinger w rozprawie doktorskiej Matki i córki. Zwiq̨zki rodzinne i artystyczne w autobiografiach kobiet po 1989 roku. 


\section{Abstract}

\section{Aleksandra Grzemska}

INDEPENDENTSCHOLAR

Mothers and Daughters in the Autobiographical Field

How do mother-daughter relationships and artistic practices find their place in the autobiographical field, and in what ways are they contingent on the mechanisms in this field? Grzemska proposes the concept of the autobiographical field to highlight the "structure of relations" between people, practices and objects, corresponding to specific areas of activity - not only social or political activity, but also literary and artistic activity. She draws on studies on the aesthetics and performativity of autobiographical writing as well as the work of Pierre Bourdieu. Exploring artistic practices in the autobiographical field, she presents case studies of selected works by visual artists Ewa Kuryluk and Zuzanna Janin, presented in the context of the artistic achievements of their mothers, Maria Kuryluk (Miriam Kohany) and Maria Anto (Antoszkiewicz).

\section{Keywords}

autobiographical field, artistic practices, Ewa Kuryluk, Zuzanna Janin, mother-daughter relationship 